\title{
SHORT-TERM IMPORT DEMAND ELASTICITIES: THE CASE OF HUNGARY
}

\author{
Ivan Novak*
}

\begin{abstract}
This paper attempts to explore the short-term dynamics of price and income import demand elasticities in the case of Hungary. Research data encompass the time period from 1996Q1 to 2018Q3. Using a relatively novel approach of T.V.P. (time-varying parameters) this paper gives further insight into the short-term dynamics of Hungarian imports. Income import demand elasticity was found to be significant and mostly positive while price effect was time-dependent and bidirectional rendering itself non-significant in the final state. Furthermore, Hungary's accession to European Union was not significantly influencing import demand patterns with other European Union members. These findings add new information to the body of knowledge regarding import trade elasticities of transition countries.
\end{abstract}

KEYWORDS: time-varying parameters, import demand, elasticities, Kalman filter, Hungary

\section{INTRODUCTION}

Trade patterns are one of the most important topics in the field of international economics. Dynamics of import elasticities offer insight into country trade relations, economic growth, macroeconomic strategies, and institutional framework. In the last few decades, Hungary has experienced market transition, exchange rate regime-switching, industrial policy transformation and in 2004 joined the European Union. Stimulated by EU funds disbursement and rising disposable income in the last ten years Hungary has experienced significant growth. Moreover, the industry was restructured from import substitution

\footnotetext{
Ivan Novak, Faculty of Economics and Business, University of Zagreb, Zagreb, Croatia; inovak1@net.efzg.hr.
} 
toward export lead growth strategy. ${ }^{1}$ Import elasticities may further reveal the properties of Hungarian import patterns. Most of the conventional approach dealing with trade elasticities is based on the assumption of stationary. Nevertheless, in the presence of structural breaks literature highlights the bias of unit root testing. Using the T.V.P. framework this paper aims to bring additional insights into the dynamics of the import demand elasticities avoiding the weakness of the conventional approach. Previous studies already employed this innovative approach examining: 1) Hungarian imports sustainability and 2) long-term effects of income and relative prices. Results confirmed the non-drifting away relationship between imports and exports ${ }^{2}$ as well as positive income and price elasticities. ${ }^{3}$ This finding was not theoretically consistent therefore short-term dynamics may offer some additional insights. Using a time-varying framework this paper aims to provide robust estimations of short-term income and price effects on Hungarian import.

The remainder of the paper encompasses five sections. The second section provides a literature overview describing previous findings regarding the topic of interest. The third section provides data description and methodology. The fourth section describes empirical findings and offers a short discussion. Finally, the fifth section summarizes the paper's findings.

\section{LITERATURE OVERVIEW}

The intertemporal marginal rate of substitution was found to have a time-varying nature therefore more easily explaining fluctuation in trade volumes. The effect was confirmed on the standard small and open economy model. ${ }^{4}$ Aggregate trade elasticity was analyzed for 28 countries with different levels of development. Results demonstrated varying elasticities attributed to the country's pattern of production. ${ }^{5}$ Using panel estimations on quarterly data in Greece, Ireland, Italy, Portugal, and Spain relative prices and demand components were

\footnotetext{
1 Novak, I.: Nonlinear adjustments in the export-led growth hypothesis: re-examining The Hungarian case, EMC Review-Časopis za ekonomiju, 18(2) 2019.

2 Bošnjak, M.: Time-varying parameters approach to sustainability of international trade flows: the case of Croatia and Serbia compared, Economic research-Ekonomska istraživanja, 32(1) 2019, p. 3684-3699.

3 Bosnjak, M.; Bilas, V.; Novak, I.: Time - varying elasticities of import demand: the cases of Czech Republic and Hungary, Statistika-Statistics and Economy Journal, 4, 2020.

4 Leibovici, F.; Waugh, M.E.; International trade and intertemporal substitution, Journal of International Economics, 117, 2019, p. 158-174.

5 Imbs, J.; Mejean, I.: Trade elasticities, Review of International Economics 25(2) 2017, p. 383-402.
} 
found to have a heterogeneous effect on import demand. The strongest influence was found in exports and private consumption. ${ }^{6}$ According to the analysis of panel data for $21 \mathrm{EU}$ member countries in the period from 1999 to $2016 \mathrm{im}$ port demand was argued to be mostly affected by income. ${ }^{7}$ Using NARDL this was confirmed for the energy sector as well. ${ }^{8}$ Furthermore, the real effective exchange rate was found to be more responsive to shocks in the non-EMU member countries especially in the period of crises while in the EU 11 countries real effective exchange rate was found to be more responsive to nominal shocks. ${ }^{9}$ Examination of the retail food price after EU enlargement in 2004 revealed evidence of $\sigma$-convergence in the direction from $8 \mathrm{CEE}$ accession countries to EU15 countries. ${ }^{10}$ Using disaggregated data in European Union in the period from 1999 to 2016 results demonstrated price dispersion reduction in 2016 in comparison to 2019. Convergence was found to be more prominent in catching-up countries and until the beginning of the global economic crisis in 2008. Crisis initiated a decrease in trade and volatility of the exchange rates both resulting in new price divergence. ${ }^{11}$ The effect of the real effective exchange rate on the trade balance was tested in the Czech Republic on quarterly data for the period from 2000 to 2014. Results exhibited the J-curve being negative in the long run and positive in the short run. ${ }^{12}$ Trade elasticity was examined for Bosnia and Herzegovina against seven leading countries from Central and Southeast Europe. Croatia and Macedonia were examined for Marshall-Lerner conditions in the short term and Slovenia in the long term. Results indicated income and price elasticity as well as the J-curve from prices to exports. ${ }^{13}$

6 Zervas, A.: The determinants of import demand in Eurozone Crisis countries-a note, Economics Bulletin, 40(3) 2020, p. 2201-2216.

7 Mirdala, R.: Global Value Chains and Export-Import Determinants in the European Union Member Countries, Journal of Advanced Research in Law and Economics (JARLE) 9(34) 2018, p. 1365-1376.

8 Fedoseeva, S.; Zeidan R.: How (a)Symmetric Is the Response of Import Demand to Changes in Its Determinants? Evidence from European Energy Imports, Energy Economics, 69, 2018, p. 379-94.

9 Mirdala, R.: Sources of Real Exchange Rate Fluctuations in New EU Member States, Ekonomický časopis 64(5) 2016, p. 440-457.

10 Lindenblatt, A.; Feuerstein, S.: Price convergence after the Eastern enlargement of the EU: evidence from retail food prices, European Review of Agricultural Economics, 42(5) 2015, p. 829-849.

11 Hałka, A.; Leszczyńska-Paczesna, A.: Price convergence in the European Union-What has changed?, Economic Modelling, 79, 2019: 226-241.

12 Gürtler, M.: Dynamic analysis of trade balance behavior in a small open economy: the J-curve phenomenon and the Czech economy, Empirical Economics 56(2) 2019, p. 469-497.

13 Kurtovic, S.; Halili, B.; Maxhuni, N.: Bilateral trade elasticity: B\&H versus its seven trade partners, 2016 
The traditional import approach was used to examine the Turkish import demand function. Quarterly import data in the period from 2003 to 2014 was found to be positively elastic to income, export, and the real exchange rate. ${ }^{14}$ Considering structural breaks Turkish demand function was analyzed in the period from 2003 to 2015 . Results revealed the time-varying nature of import demand and confirmed negative income elasticity present in the short-run and the long-run while negative price elasticity was present only in the long run. ${ }^{15}$ Additionally, the Turkish case was examined by the state-space model. Import function was fitted for aggregate imports and components using quarterly data covering the time period from 2003 to 2018. Results confirmed positive price and income elasticities. Furthermore, the role of determinants changed over time emphasizing prices. ${ }^{16}$

Examining productivity, a recent study showed that importing all inputs from abroad would increase Hungarian firms' revenue by $22 \%$ and half of the effect would be attributed to imperfect substitution. One-quarter of the productivity growth realized in the period from 1993 to 2002 was accomplished solely on account of importing inputs. ${ }^{17}$ Analyzing data in the period from 1993 to 2014 Hungarian trade was found to follow the Linder hypothesis orienting toward countries with a similar level of development and factor endowments emphasizing differentiating strategy. ${ }^{18}$ A study examining integration and trade specialization confirmed the relationship between specialization and the level of development for selected CEE countries including Hungary. ${ }^{19}$ Furthermore using a time-varying approach Hungarian import-export relationship was found sustainable and after various shocks readjusting to the previous balance. ${ }^{20}$

14 Çakmak, U.; Çakmak, A. G. Ö. A.: The key determinants of the import and policy recommendations for Turkish economy, Journal of Economics and Sustainable Development 7(6) 2016, p. 96-103.

15 Bayramoglu, A. T.; Sukruoglu, D.: Non-Energy import demand function in Turkey: New evidence, Asian Economic and Financial Review 6(12) 2016, p. 750.

16 Çulha, O.Y.; Eren, O; and Öğünç, F.; Import demand function for Turkey, Central Bank Review 19(1) 2019, p. 9-19.

17 Halpern, L.; Koren, M.; Szeidl, A.: Imported inputs and productivity. American Economic Review, 105(12), 2015, p. 3660-3703.

18 Erdey, L.; Pöstényi, A.: Determinants of the exports of Hungary: Trade theory and the gravity model. Acta Oeconomica, 67(1) 2017, p. 77-97.

19 Pascariu, G.C; Drăgan, G.; Stângaciu, O.A.: Specialization in Central and Eastern European countries: Towards a new core-periphery structural differentiation?, Romanian Journal of Economic Forecasting, 22(3) 2019, p. 148.

20 Bošnjak, M.: Time-varying parameters approach to sustainability of international trade flows: the case of Croatia and Serbia compared, Economic research-Ekonomska istraživanja, 32(1) 2019, p. 3684-3699. 
Literature offers various evidence from countries with different level of economic development often revealing the time-dependent nature of trade elasticities. The time-varying framework is applied to generate robust and accurate estimates of the Hungarian short-term import elasticities.

\section{RESEARCH DATA AND METHODOLOGY}

The research data sample has consisted of quarterly time series in the period from 1996Q1 to 2018Q3. Time series of national income in constant prices and imports are retrieved from the National Bureau of Statistics of Hungary while real effective exchange rate toward 19 EMU (European Monetary Union) countries was retrieved from Eurostat. To avoid the problem of seasonality selected time series were adjusted by the X13 ARIMA procedure. Furthermore, time series are converted to natural logarithmic form, and coefficients are interpreted as elasticities. The methodology is acquired and adjusted from the paper examining T.V.P. of Croatian import demand by Bošnjak in $2019^{21}$. Underlying theory assuming imperfect substitutions between imported and exported goods describes the import function demand equation as follows (1):

$$
I=f\left(Y_{d}, P_{d}, P_{f}\right)
$$

Import demand (I) of a country is expected to be positively related to national income $\left(\mathrm{Y}_{\mathrm{d}}\right)$ and domestic prices $\left(\mathrm{P}_{\mathrm{d}}\right)$ while negatively related to foreign prices $\left(\mathrm{P}_{\mathrm{f}}\right)$. Therefore, relative prices $\left(\mathrm{P}_{\mathrm{f}} / \mathrm{P}_{\mathrm{d}}\right)$ are also positively correlated to import demand. Nevertheless, due to delay in capital reallocation relative prices may have different short and long-term effects on imports (Crucini and Davis, 2016). In order to estimate the function of import demand, this paper employs time-varying modeling (T.V.P.) within the state-space model. The general form of the T.V.P. model within the state-space model incorporates measurement (2) and transition (3) equations described as follows:

$$
\begin{gathered}
Y_{t}=X_{t}^{\prime} \beta_{t}+\varepsilon_{t}, \quad \varepsilon_{t} \sim \operatorname{IIDN}\left(0, \sigma^{2}\right) \\
\beta_{t}=\theta+\Gamma \beta_{t-1}+v_{t}, \quad v_{t} \sim \operatorname{IIDN}(0, Q), \quad E\left(\varepsilon_{t} v_{t}\right)=0
\end{gathered}
$$

Where:

$Y_{t}-1 \mathrm{x} 1$ vector representing observed dependent variable,

${ }^{21}$ Bošnjak, M.: Time-varying parameters approach to sustainability of international trade flows: the case of Croatia and Serbia compared, Economic research-Ekonomska istraživanja, 32(1) 2019, p. 3684-3699. 
$X_{\mathrm{t}}-\mathrm{kx} 1$ vector representing observed explanatory variables,

$\beta_{\mathrm{t}}-\mathrm{kx} 1$ vector representing unobserved variables,

$\Gamma-$ kxk matrix of constant parameters,

$\varepsilon_{\mathrm{t}}-$ error term in equation (2),

$v_{t}-$ error term in equation (3) and

$Q$ - the diagonal variance-covariance matrix.

Using Kalman (1960) filter estimates of the unobserved time-varying coefficients $\left(\beta_{t}\right)$ are filtered and smoothed recursively. The prediction equation (4) and the covariance matrix (5) are provided as follows:

$$
\begin{gathered}
\hat{\beta}_{t \mid t-1}=\Gamma \hat{\beta}_{t-1} \\
P_{t \mid t-1}=\Gamma P_{t-1} \Gamma^{\prime}+Q_{t}
\end{gathered}
$$

Accordingly, the estimates were adjusted recursively resulting from the equations (5) and (6) as follows.

$$
\begin{gathered}
\hat{\beta}_{t}=\beta_{t \mid t-1}+P_{t \mid t-1} X\left(Y_{t}-X^{\prime} \hat{\beta}_{t \mid t-1}\right)\left(X P_{t \mid t-1} X+H_{t}\right) \\
P_{t}=P_{t \mid t-1}-P_{t \mid t-1} X^{\prime} X P_{t \mid t-1}^{\prime} /\left(X^{\prime} P_{t \mid t-1} X+H_{t}\right)
\end{gathered}
$$

In continuation, the import demand function in the case of Hungary is provided with logarithmic values as follows (8) to (12):

$$
\begin{gathered}
\Delta \ln \left(I_{t}\right)=\alpha_{t}+\beta_{1, t} \Delta \ln \left(Y_{t}\right)+\beta_{2, t} \ln \left(\operatorname{REER}_{t}\right)+\beta_{3, t} \mathrm{EU}+\varepsilon_{t}, \quad \varepsilon_{t} \sim \operatorname{IIDN}\left(0, \sigma^{2}\right) \\
\alpha_{t}=\alpha_{t-1}+v_{0, t}, \quad v_{0, t} \sim \operatorname{IIDN}\left(0, \sigma_{v 0}^{2}\right) \\
\beta_{1, t}=\beta_{1, t-1}+v_{1, t}, \quad v_{1, t} \sim \operatorname{IIDN}\left(0, \sigma_{v 1}^{2}\right) \\
\beta_{2, t}=\beta_{2, t-1}+v_{2, t}, \quad v_{2, t} \sim \operatorname{IIDN}\left(0, \sigma_{v 2}^{2}\right) \\
\beta_{3, t}=\beta_{3, t-1}+v_{3, t}, \quad v_{3, t} \sim \operatorname{IIDN}\left(0, \sigma_{v 3}^{2}\right)
\end{gathered}
$$

Where (8) is the measurement equation and (9), (10), (11), and (12) are the state equations. State equations describe that the new state value is a linear combination of the former state value and an error process $v_{j, t}$. The measurement equation represents the relationship between observed variables and transition variables. Observed dependent variable $\Delta \ln \left(I_{t}\right)$ represents the change in the 
natural logarithmic value of imports $\left(I_{t}\right)$, while explanatory variables $\Delta \ln \left(Y_{t}\right)$ and $\Delta \ln \left(\mathrm{REER}_{t}\right)$ represent the change in the natural logarithmic value of the national income and change in the natural logarithmic value of the real effective exchange rate respectively, while dummy variable represents the EU membership. Selected explanatory variables describe the relationship between the observable dependent variable and the unobservable time-varying coefficients. Coefficients $\alpha_{t}, \beta_{1 t}, \beta_{2 t}$, and $\beta_{3 t}$ are unobserved time-varying parameters aiming to be estimated by the model. $\varepsilon_{t}$ and $v_{0, t}$ represent the error term in the measurement and state equations, respectively. The model in the following equations (8), (9), (10), (11), and (12) represent initial conditions of the state space form. The estimates of the state space were provided using the Kalman filter while the estimates of the parameters in the equations were obtained by maximizing the Likelihood function. Kalman filter as a recursive process needs plausible initial values which are provided by the OLS estimations. The described process is used to estimate the time-varying nature of the Hungarian import determinants.

\section{RESULTS AND DISCUSSION}

The following described data and methodology results for Hungarian income and price import elasticities are provided in Table 1 and Table 2. The results in Table 1 provide the OLS model estimations used for initial values in the TVP approach.

Table 1 Estimates (OLS) of import demand: the case of Hungary

\begin{tabular}{|l|c|c|c|c|}
\hline & $\begin{array}{c}\text { Coeff. } \\
\text { Estimates }\end{array}$ & Root MSE & z-statistic & p-value \\
\hline $\boldsymbol{\alpha}($ Constant $)$ & 0.017881 & 0.009677 & 1.848 & 0.0681 \\
\hline$\Delta \ln (\boldsymbol{Y})($ Income $)$ & 0.908611 & 0.209742 & 4.332 & $3.98 \mathrm{e}-05$ \\
\hline $\begin{array}{l}\Delta \ln (\boldsymbol{R E E R})(\text { Real } \\
\text { effective exchange rate) }\end{array}$ & 0.193115 & 0.105579 & 1.829 & 0.0708 \\
\hline $\begin{array}{l}\text { EU (EU membership - } \\
\text { dummy variable) }\end{array}$ & -0.012441 & 0.008641 & -1.440 & 0.1536 \\
\hline Adjusted R-squared: 0.382 & F-statistic: 19.34 & p-value: $1.133 \mathrm{e}-09$ \\
\hline Diagnostic tests: & p-value: 0.03856 \\
\hline Ljung-Box Test: 21.909 & p-value: 0.6041 \\
\hline Jarque Bera Test: 1.008 & p-value: 0.9071 \\
\hline ARCH Test: 6.1738 &
\end{tabular}

Source: Authors' calculation 
According to the OLS import demand in Hungary is on average elastic to income (0.9086) and price (0.1931) while income elasticity is higher. Comparing to Croatian income (1.6075) and price (0.6984) elasticities ${ }^{22}$ Hungarian $^{2}$ results were less prominent. This result is consistent with baseline theory. In the short-term rising relative prices rarely reorient demand from imported to local goods. According to OLS estimations, EU membership was not significant in describing Hungarian imports. This may be partially explained by the fact that the integration process started much earlier than Hungary has joined the European Union in 2004. Estimations are valid since model diagnostics do not indicate model misspecification. Autocorrelation and heteroscedasticity are not present, and residuals are normally distributed making these estimations plausible initial values for the T.V.P. framework.

The results in Table 2 provide final estimations of the T.V.P. framework while the time-varying nature of the coefficients is observable in Figure 2 and Figure 3 in the Appendix.

Table 2 Time varying determinants of short-term import demand: the case of Hungary

\begin{tabular}{|l|c|c|c|c|}
\hline & Final state & Root MSE & z-statistic & p-value \\
\hline$\alpha$ (Constant) & 0.01480796 & 0.01532471 & 0,966279949 & 0.1669521 \\
\hline$\Delta \ln (\boldsymbol{Y})($ Income $)$ & 0.99097986 & 0.64622195 & 1,533497678 & 0.0625766 \\
\hline $\begin{array}{l}\Delta \ln (\boldsymbol{R E E R}) \text { (Real } \\
\text { effective exchange rate) }\end{array}$ & 0.861755807 & 0.89923596 & 0,958320002 & 0.1689507 \\
\hline $\begin{array}{l}\text { EU (EU membership - } \\
\text { dummy variable) }\end{array}$ & -0.01117195 & 0.01551346 & $-0,720145603$ & 0.2357177 \\
\hline Log likelihood: $\mathbf{- 1 5 4 . 3 6 4 7}$ & AIC:- 290.7294 \\
\hline Diagnostic tests: & p-value: 0.05838 \\
\hline Ljung-Box Test: 20.489 & p-value: 0.7847 \\
\hline Jarque Bera Test: $\mathbf{0 . 4 8 4 7 9}$ & p-value: 0.08299 \\
\hline ARCH Test: 19.236 &
\end{tabular}

Source: Authors' calculation

Short-term income elasticity under the T.V.P. framework in the final state is significant (0.9909) and higher than OLS. Figure 2 provides the evolution of the income elasticity in the Hungarian import demand. For most of the observed

22 Bošnjak, M.: Time-varying parameters approach to sustainability of international trade flows: the case of Croatia and Serbia compared, Economic research-Ekonomska istraživanja, 32(1) 2019, p. 3684-3699. 
period, it was positive except for 2002 and 2011. In the year 2002 Hungarian economy had just applied a further round of liberalization with the European community promoting partially or full removal of import duties as well as commitment to abandon export refunds in certain EU industries which may partially explain the negative short-term relationship between income and imports. In 2012 Hungarian economy experienced a recession therefore partially explaining the negative income elasticity. In Croatia, there was no volatility of income elasticity. Croatian elasticity was above unity for the entire period of observation in the final state reaching $1.7829^{23}$. Short-term price elasticity under the T.V.P. framework in the final state was found non-significant (0.8617) in Hungary. Figure 3 provides the evolution of the price elasticity in time. There was no evidence of price convergence like the one found in Croatia $^{24}$ and the short-term price elasticity in Hungary presented a volatile nature. The theory implies a positive short-term relationship yet there have been significant deviations in the period of economic crises 2008, 2012, and 2015. This may present the risk of higher future inflation, especially in catching-up countries ${ }^{25}$. Common monetary policy is found to be less than ideal for similar scenarios ${ }^{26}$. Additionally, the non-significant relationship of the Hungarian imports and EU membership was confirmed under the time-varying framework as well implying import adjustments happening previous to the formal accession.

\section{CONCLUSION}

This paper brings several important conclusions. Extensive literature brings evidence from various countries. Outcomes may not necessarily follow the baseline theory and depended on time, methodological approach, and country specifics. The time-varying parameters approach avoids some weakness of the conventional time series analysis providing insight into the development of income and price elasticity over time. Hungarian price elasticities revealed the lack of price convergence despite the Hungarian accession to the membership of the European Union in 2004. Even the volume of import was not significantly influenced

23 Bošnjak, M.: Time-varying parameters approach to sustainability of international trade flows: the case of Croatia and Serbia compared, Economic research-Ekonomska istraživanja, 32(1) 2019, p. 3684-3699.

24 Bošnjak, M.: Time-varying parameters approach to sustainability of international trade flows: the case of Croatia and Serbia compared, Economic research-Ekonomska istraživanja, 32(1) 2019, p. 3684-3699.

25 Hałka, A.; Leszczyńska-Paczesna, A.: Price convergence in the European Union - What has changed?, Economic Modelling, 79, 2019: 226-241.

26 Konopczak, K.; Welfe, A.: Convergence-driven inflation and the channels of its absorption, Journal of Policy Modeling, 39(6) 2017, p. 1019-1034. 
by Hungary joining the EU. Short-term income and price elasticity were positive for most of the observed period with few exceptions related to trade negotiations and economic crises. The limitation of the paper stems from the fact that the results describe import trade patterns of Hungary and 19 European Monetary Union countries without considering other trade partners. This inclusion may lead to different results for import elasticities. Furthermore, this paper is using aggregate variables while exploring the subsectors of the Hungarian imports may bring even more insights into the Hungarian import patterns. Limitations of this paper may serve as a starting point for future import elasticity research.

\section{LITERATURE}

1. Bayramoglu, A. T.; Sukruoglu, D.: Non-Energy import demand function in Turkey: New evidence, Asian Economic and Financial Review 6(12) 2016, p. 750.

- DOI: https://doi.org/10.18488/journal.aefr/2016.6.12/102.12.750.761

2. Bošnjak, M.: Time-varying parameters approach to sustainability of international trade flows: the case of Croatia and Serbia compared, Economic research-Ekonomska istraživanja, 32(1) 2019, p. 3684-3699.

- DOI: https://doi.org/10.1080/1331677X.2019.1674177

3. Bošnjak, M.; Bilas, V.; Novak, I.: Time - varying elasticities of import demand: the cases of Czech Republic and Hungary, Statistika-Statistics and Economy Journal, 4, 2020.

4. Çakmak, U.; Çakmak, A. G. Ö. A.: The key determinants of the import and policy recommendations for Turkish economy, Journal of Economics and Sustainable Development 7(6) 2016, p. 96-103.

5. Crucini, M.; Davis, J.S.: Distribution Capital and the Short- and Long-Run Import Demand Elasticity, Journal of International Economics, 100(C) 2016, pp. 203-19.

- DOI: https://doi.org/10.1016/j.jinteco.2016.03.010

6. Çulha, O.Y.; Eren, O; and Öğünç, F.; Import demand function for Turkey, Central Bank Review 19(1) 2019, p. 9-19.

- DOI: https://doi.org/10.1016/j.cbrev.2019.03.001

7. Erdey, L.; Pöstényi, A.: Determinants of the exports of Hungary: Trade theory and the gravity model. Acta Oeconomica, 67(1) 2017, p. 77-97.

- DOI: https://doi.org/10.1556/032.2017.67.1.5

8. Fedoseeva, S.; Zeidan R.: How (a)Symmetric Is the Response of Import Demand to Changes in Its Determinants? Evidence from European Energy Imports, Energy Economics, 69, 2018, p. 379-94.

- DOI: https://doi.org/10.1016/j.eneco.2017.12.009 
9. Gürtler, M.: Dynamic analysis of trade balance behavior in a small open economy: the J-curve phenomenon and the Czech economy, Empirical Economics 56(2) 2019, p. 469-497.

- DOI: https://doi.org/10.1007/s00181-018-1445-4

10. Hałka, A.; Leszczyńska-Paczesna, A.: Price convergence in the European Union-What has changed?, Economic Modelling, 79, 2019: 226-241.

- DOI: https://doi.org/10.1016/j.econmod.2018.11.002

11. Halpern, L.; Koren, M.; Szeidl, A.: Imported inputs and productivity. American Economic Review, 105(12), 2015, p. 3660-3703.

- DOI: https://doi.org/10.1257/aer.20150443

12. Imbs, J.; Mejean, I.: Trade elasticities, Review of International Economics 25(2) 2017, p. 383-402.

- DOI: https://doi.org/10.1111/roie.12270

13. Konopczak, K.; Welfe, A.: Convergence-driven inflation and the channels of its absorption, Journal of Policy Modeling, 39(6) 2017, p. 1019-1034.

- DOI: https://doi.org/10.1016/j.jpolmod.2017.02.001

14. Kurtovic, S.; Halili, B.; Maxhuni, N.: Bilateral trade elasticity: B\&H versus its seven trade partners, 2016

- DOI: https://doi.org/10.1515/roe-2017-0012

15. Leibovici, F.; Waugh, M.E.; International trade and intertemporal substitution, Journal of International Economics, 117, 2019, p. 158-174.

- DOI: https://doi.org/10.1016/j.jinteco.2018.11.007

16. Lindenblatt, A.; Feuerstein, S.: Price convergence after the Eastern enlargement of the EU: evidence from retail food prices, European Review of Agricultural Economics, 42(5) 2015, p. 829-849.

- DOI: https://doi.org/10.1093/erae/jbu038

17. Mirdala, R.: Sources of Real Exchange Rate Fluctuations in New EU Member States, Ekonomický časopis 64(5) 2016, p. 440-457.

- DOI: https://doi.org/10.18267/j.polek.1077

18. Novak, I.: Nonlinear adjustments in the export-led growth hypothesis: re-examining The Hungarian case, EMC Review-Časopis za ekonomiju, 18(2) 2019.

- DOI: https://doi.org/10.7251/EMC1902298N

19. Pascariu, G.C; Drăgan, G.; Stângaciu, O.A.: Specialization in Central and Eastern European countries: Towards a new core-periphery structural differentiation?, Romanian Journal of Economic Forecasting, 22(3) 2019, p. 148.

20. Zervas, A.: The determinants of import demand in Eurozone Crisis countries-a note, Economics Bulletin, 40(3) 2020, p. 2201-2216. 


\section{APPENDIX}

Figure 1 Time evolution of the $\alpha$ coefficient in T.V.P. import demand function

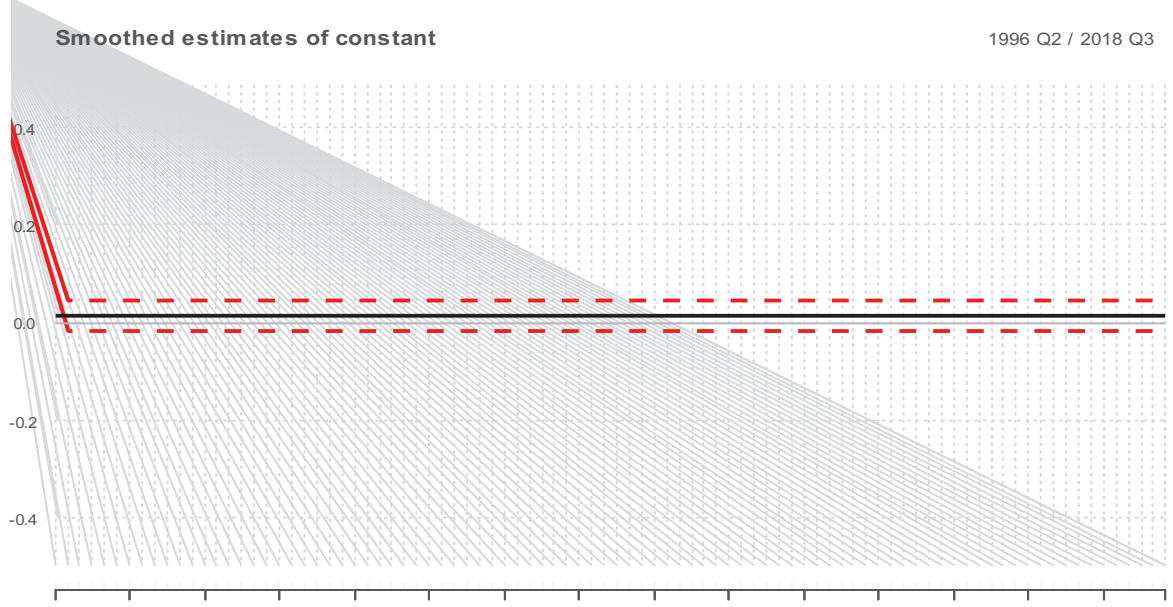

1996-Q2 $1997-Q 4 \quad$ 1999-Q2 $2000-Q 4 \quad 2002-Q 2 \quad 2003-Q 4 \quad 2005-Q 2 \quad 2006-Q 4 \quad 2008-Q 2 \quad 2009-Q 4 \quad 2011-Q 2 \quad 2012-Q 4 \quad 2014-Q 2 \quad 2015-Q 4 \quad 2017-Q 2$

Source: Authors' calculations

Figure 2 Time evolution of income elasticity in T.V.P. import demand function

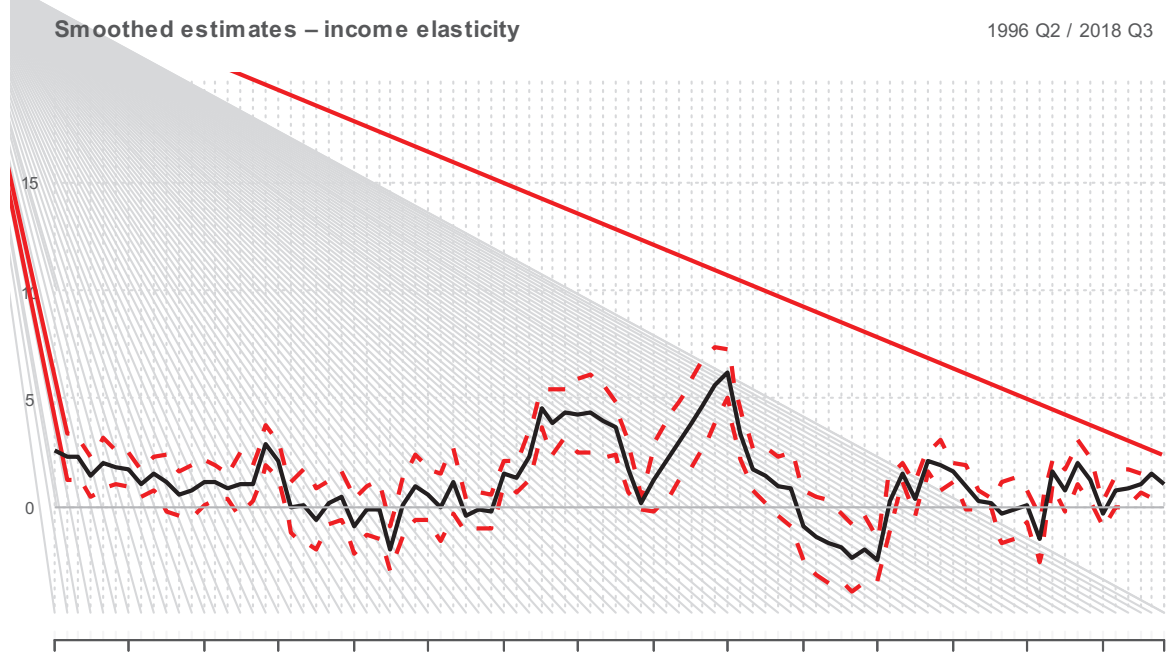

1996-Q2 $\quad$ 1997-Q4 $\quad$ 1999-Q2 $2000-Q 4 \quad 2002-Q 2 \quad 2003-Q 4 \quad 2005-Q 2 \quad 2006-Q 4 \quad 2008-Q 2 \quad 2009-Q 4 \quad 2011-Q 2 \quad 2012-Q 4 \quad 2014-Q 2 \quad 2015-Q 4 \quad 2017-Q 2$

Source: Authors' calculations 
Figure 3 Time evolution of the price elasticity in T.V.P. import demand function

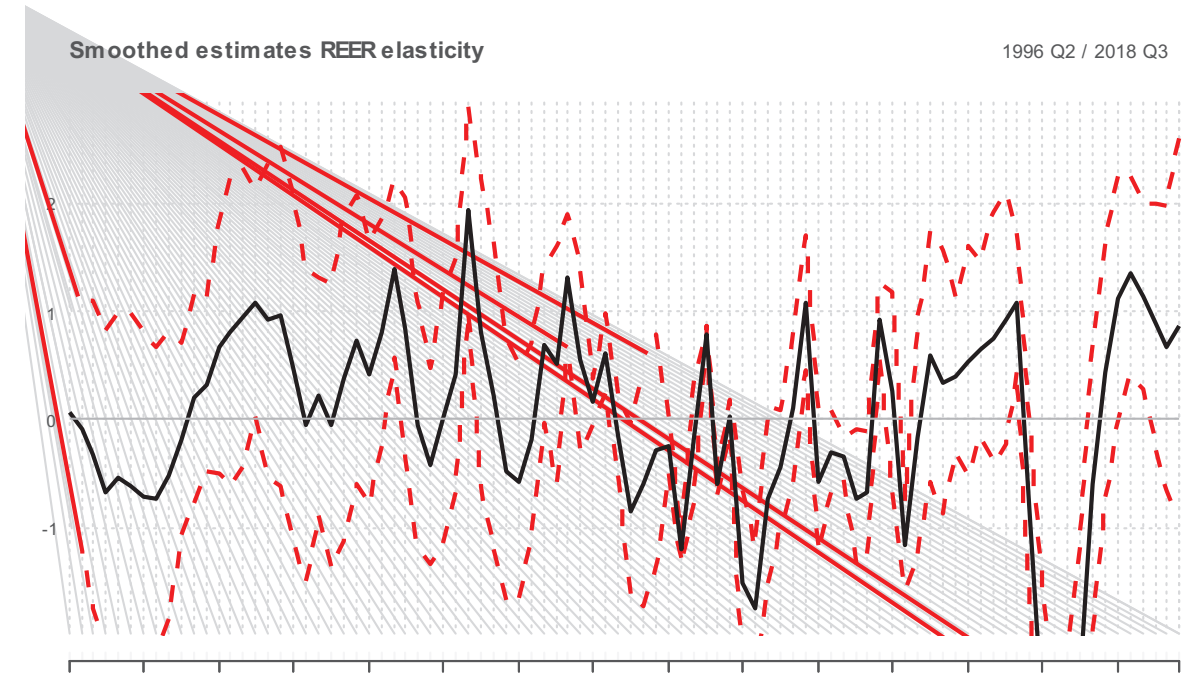

1996-Q2 1997-Q4 1999-Q2 2000-Q4 2002-Q2 2003-Q4 2005-Q2 2006-Q4 2008-Q2 2009-Q4 2011-Q2 2012-Q4 2014-Q2 2015-Q4 2017-Q2

Source: Authors' calculations

Figure 4 Time evolution of the EU membership in T.V.P. import demand function

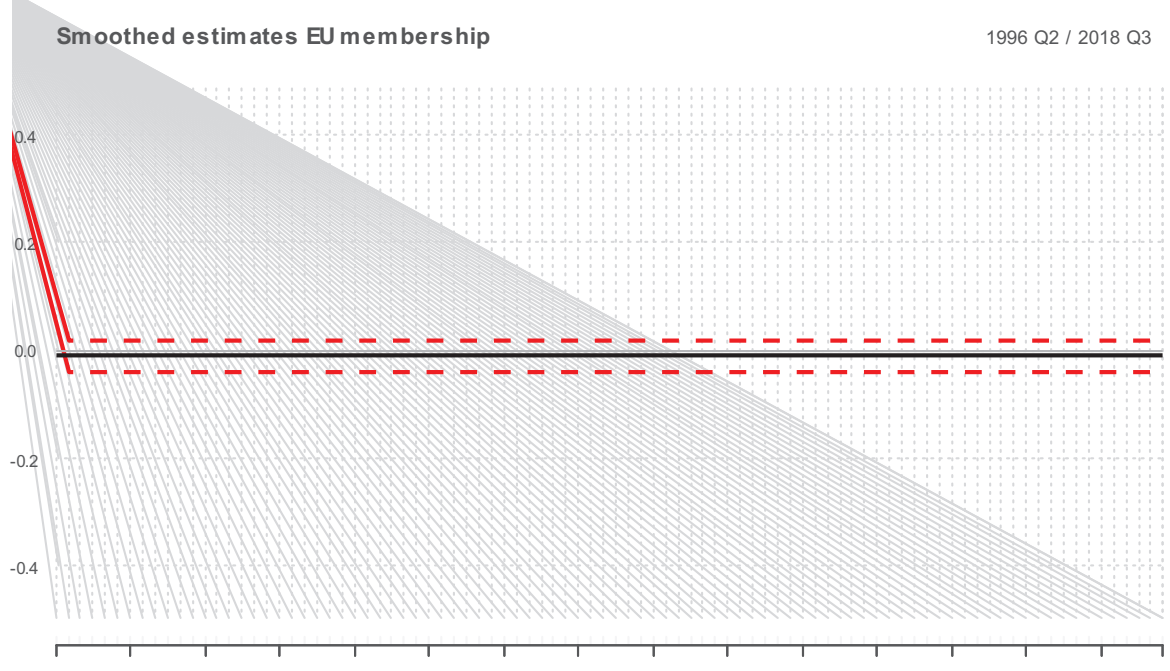

1996-Q2 $1997-Q 4 \quad$ 1999-Q2 2000-Q4 2002-Q2 2003-Q4 2005-Q2 2006-Q4 2008-Q2 2009-Q4 2011-Q2 2012-Q4 2014-Q2 2015-Q4 2017-Q2

Source: Authors' calculations 